\title{
PELUANG PSIKOEDUKASI KELUARGA UNTUK PENCEGAHAN KEKAMBUHAN ORANG DENGAN GANGGUAN JIWA DI PAPUA
}

\author{
Nasrah Halim $^{1}$, Achir Yani Syuhaimie Hamid ${ }^{2}$ \\ ${ }^{1}$ Rumah Sakit Jiwa Daerah Abepura Papua, Jl. Kesehatan No.II, Awiyo, Abepura, Kota Jayapura, Papua, Indonesia \\ 99351 \\ ${ }^{2}$ Fakultas Ilmu Keperawatan, Universitas Indonesia, Pondok Cina, Kecamatan Beji, Kota Depok, Jawa Barat, Indonesia \\ 16424 \\ *halimkepnasrah@gmail.com
}

\begin{abstract}
ABSTRAK
Psikoedukasi keluarga dapat digunakan sebagai alternatif pencegahan kekambuhan Orang Dengan Gangguan Jiwa (ODGJ) khususnya di Papua yang memiliki keterbatasan sumberdaya kesehatan antara lain kemampuan mengakses fasilitas layanan kesehatan, dan keterbatasan tenaga kesehatan. Kondisi ini diperberat dengan banyaknya jumlah ODGJ serta keadaan geografis yang sulit. Artikel ini bertujuan menguraikan peluang psikoedukasi keluarga dalam mengatasi keterbatasan sumberdaya kesehatan di Papua. Metode yang digunakan adalah review sistematis (systematic review) pada artikel yang dipublikasikan di database elektronik nasional maupun internasional. Jurnal Lokal menggunakan pencarian google sedangkan jurnal internasional menggunakan database ProQuest, Sage Publications, Science Direct SpringerLink. Dan Wiley Online. Kriteria inklusi meliputi psikoedukasi keluarga yang berfokus dalam pencegahan kekambuhan dan pemulihan ODGJ baik di Indonesia dengan rentang tahun 2018-2020 sedangkan Internasional rentang tahun 2015-2020. Hasil didapatkan 1464 artikel ekstraksi 33 artikel yang relevan yang kemudian penulis mengidentifikasi 21 artikel yang menunjukkan efektivitas psikoedukasi keluarga dalam pencegahan kekambuhan ODGJ baik pada jurnal nasional maupun internasional.
\end{abstract}

Kata kunci: pencegahan kekambuhan, psikoedukasi keluarga

\section{OPPORTUNITIES FOR FAMILY PSYCHEDUCATION FOR RELAPSE PREVENTION OF PEOPLE WITH THE MENTAL DISORDER IN PAPUA}

\begin{abstract}
Family psychoeducation can be used as an alternative relapse prevention of people with mental disorders (PWMD), especially in Papua, which has limited health resources both health care facilities, health workers, the number of ODGJ and geographical conditions. The purpose of this article is to identify opportunities for family psychoeducation in overcoming the limitations of health resources in Papua. The method used is a systematic review of articles published in national and international electronic databases. Local journals use Google search while international journals use ProQuest, Sage Publications, Science Direct SpringerLink databases. And Wiley Online. Inclusion criteria include family psychoeducation which focuses on relapse prevention and recovery of PWMD both in Indonesia in the range 2018-2020 while International ranges in 2015-2020. The results obtained were 1464 articles extracted 33 relevant articles which then the authors identified 21 articles that show the effectiveness of family psychoeducation in preventing PWMD recurrence in both national and international journals.
\end{abstract}

Keywords: family psychoeducation, relapse prevention

\section{PENDAHULUAN}

Laporan World Health Organization (WHO) tahun 2016 menunjukkan bahwa gangguan jiwa dialami oleh sekitar 450 juta orang di seluruh dunia dengan perkiraan $10 \%$ orang dewasa, dan $25 \%$ pada usia tertentu seseorang diprediksi akan mengalami gangguan jiwa (Kementerian Kesehatan; 2018); diperkirakan berkembang mencapai $25 \%$ dari total penduduk dunia pada tahun 2030 (Charlson, et. al, 2019). Di Indonesia sendiri prevalensi orang dengan gangguan jiwa
(ODGJ) pada tahun 2013 dan 2018 meliputi Skizofrenia meningkat dari 1,7 permil menjadi 7,0 permil; depresi mengalami peningkatan tipis diangka 6 permil menjadi 6,1 permil; sedangkan mental emosional dari 6 menjadi 9,8 permil. Sama dengan kondisi Nasional Papua dan Papua Barat juga mengalami kenaikan skizofrenia dari 1,2 tahun 2013 menjadi 4,5 permil pada tahun 2018; gangguan emosional dari 4,2 menjadi 8,5 permil; sedangkan depresi diangka 4,0 permil lebih rendah dari Nasional. Sedangkan di Papua Barat untuk 
skizofrenia dari 1,6 permil ditahun 2013 menjadi 6,8 permil tahun 2018; gangguan mental emosional tahun 2013 sebesar 2,5 permil menjadi 11,3 permil tahun 2018; dan depresi tercatat lebih tinggi dari Nasional pada tahun 2018 yakni 7,4 permil (Riset Kesehatan Dasar, 2018).

Papua merupakan salah satu provinsi di Indonesia yang hanya memiliki satu rumah sakit jiwa yakni Rumah Sakit Jiwa Daerah (RSJD) Abepura. Rumah sakit jiwa ini melayani pasien di provinsi Papua namun tidak jarang juga melayani provinsi Papua Barat. Sementara Provinsi Papua memiliki 29 Kabupaten Kota dengan luas wilayah 319.036 $\mathrm{km}^{2}$ (Papua.go.id, 2019); dengan total penduduk 3.322.526 jiwa (BPSa, 2019). Luas wilayah dan faktor geografis yang umumnya terdiri dari gunung dan lembah serta infrastruktur yang masih minim maka transportasi yang familiar dan umum digunakan untuk mencapai satu Kabupaten ke Kabupaten lainnya menggunakan trasnportasi udara. Hal ini semakin mempersulit kondisi ODGJ untuk mendapatkan layanan kesehatan. Sehubungan dengan hal tersebut, salah satu solusi sebagai alternatif yang diperkirakan dapat menutupi keterbatasan fasilitas layanan di Provinsi Papua dengan memaksimalkan dukungan keluarga dalam proses penyembuhan dan kekambuhan ODGJ. Berdasarkan pada pertimbangan bahwa gangguan jiwa merupakan salah satu penyakit kronis yang penyembuhannya membutuhkan waktu jangka panjang, maka pengobatan yang dilakukan di RSJD hanya menyembuhkan dalam waktu tertentu saja. Penderita gangguan jiwa harus dikembalikan ke lingkungan keluarga. Pengembalian tersebut dapat terjadi karena keterbatasan fasilitas yang dimiliki oleh RSJD Abepura yang hanya memiliki 104 tempat tidur. Diharapkan proses penyembuhan total ODGJ dapat dilakukan dengan mekanisme rawat jalan dengan bantuan keluarga (Kyriopoulos, et. al, 2016; Suhermi \& Jama, 2019).

Dukungan keluarga dalam menunjang proses kesembuhan dan pencegahan kekambuhan diantaranya berbentuk pengharapan, informasi dan emosioanl (Eni \& Herdiyanto, 2018); pemenuhan kebutuhan sehari-hari, dukungan pada akses ke fasilitas layanan kesehatan termasuk pengobatan, perlibatan aktif ODGJ dalam keluarga dan komunikasi (Kyriopoulos, et. al, 2016). Namun kenyataannya dukungan tersebut tidak berjalan maksimal sehingga malah membuatnya menjadi salah satu factor pemicu kekambuhan.
Salah satu metode untuk menunjang pemulihan dan mencegah kekambuhan ODGJ di rumah yakni psikoedukasi keluarga. Psikoedukasi Keluarga digunakan dalam rangka memberikan informasi tentang kesehatan mental dan keterampilan berupa mengekspresikan emosi dan menghindari perawatan salah terhadap ODGJ untuk meningkatkan kemampuan sebagai pelaku asuh (caregiver) yang merawat ODGJ (Sin, Gillard, Spain, Cornelius, Chene, \& Henderson, 2017). Manfaat Psikoedukasi Keluarga antara lain memberikan informasi masalah kesehatan jiwa, cara pengambilan keputusan terhadap pengobatan, melakukan keperawatan pada anggota keluarga yang sakit, melaksanakan tugas memantau kesehatan keluarga, dan pemeriksaan ke layanan kesehatan (Maglaya, 2009). Sedangkan tujuan Psikoedukasi Keluarga meningkatkan kemampuan dan pengetahuan keluarga dalam merawat anggotanya yang mengalami gangguan jiwa (Dewi, Daulima, \& Wardan, 2019). Selain itu, terapi ini juga dapat membantu keluarga dalam mengambil tindakan pengobatan bagi anggota keluarga dengan masalah kesehatan jiwa, sehingga kemampuan keluarga untuk mengakses pelayanan kesehatan juga semakin meningkat (Ngoc, Weiss, \& Trung, 2016). Penelitian terkait psikoedukasi dalam mencegah kekambuhan sudah umum dilaksanakan di dunia maupun di Indonesia, namun sepanjang pengetahuan dan pencarian dengan database publikasi penelitian yang penulis lakukan belum pernah dilakukan di Papua. Untuk itu, pada artikel ini akan menguraikan peluang psikoedukasi keluarga dalam upaya pencegahan kekambuhan ODGJ di Papua yang memiliki keterbatasan sumber daya baik fasilitas layanan kesehatan, tenaga kesehatan dan factor geografis serta transportasi yang tersedia di Papua.

\section{METODE}

Tulisan ini menggunakan pendekatan systematic review untuk mengidentifikasikan artikel baik Nasional maupun Internasional. Pencarian artikel Nasional menggunakan bantuan google penelusuran lanjutan dengan katan kunci [(psikoedukasi keluarga) dan (pencegahan kembuhan) dan (orang dengan gangguan jiwa)]; domain website [ac.id] dan rentan tahun [20182020] sedangkan artikel Internasional menggunakan database eletronik antara lain: ProQuest, Sage Publications, Science Direct dan SpringerLink dengan kata kunci (family psychoeducation) AND (Relapse Prevention) AND (People with Mental Illness) tahun 2015- 
2020. Penulis melakukan tiga tahapan seleksi, diantaranya seleksi berdasarkan kata kunci yang, abstraksi dan terakhir azas kemanfaatan. Seleksi berdasarkan kata kunci penulis menemukan total jumlah artikel 1464 yang terdiri dari 700 artikel Jurnal Nasional dan 764 artikel Jurnal Internasional. Dari total 1464 artikel tersebut penulis melakukan seleksi abstraksi sehingga berjumlah 33 dan kemudian seleksi berdasarkan azas kemanfatan psikoedukasi keluarga pada ODGJ penulis menemukan hanya 21 artikel.
HASIL

Penulis mengidentifikasikan sejumlah artikel dengan penggunaan kata kunci yang tersebut di atas dan menghasilkan beberapa artikel yang kemudian penulis melakukan seleksi berdasarkan judul, intisari dan kriteria yang telah ditentukan. Adapun hasil penelusuran tersebut dapat dilihat pada tabel 2 dan 3 dibawah ini.

Tabel 1.

Hasil penelusuran artikel

\begin{tabular}{|c|c|c|c|c|c|}
\hline Database & $\begin{array}{c}\text { Sebelum } \\
\text { seleksi }\end{array}$ & $\begin{array}{c}\text { Seleksi } \\
\text { ke-2 }\end{array}$ & $\begin{array}{l}\text { Artikel } \\
\text { terakhir }\end{array}$ & $\begin{array}{l}\text { Rentang } \\
\text { Tahun }\end{array}$ & Keterangan \\
\hline Google & 700 & 9 & 5 & 2018-2020 & $\begin{array}{l}\text { Jurnal } \\
\text { negeri) }\end{array}$ \\
\hline ProQuest & 223 & 9 & 9 & \multirow[t]{5}{*}{$2015-2020$} & \multirow{5}{*}{$\begin{array}{l}\text { Jurnal Internasional (Luar } \\
\text { Negeri) }\end{array}$} \\
\hline Sage Pubclications & 138 & 1 & 1 & & \\
\hline Science Direct & 315 & 6 & 4 & & \\
\hline SpringerLink & 88 & 3 & 2 & & \\
\hline Total & 1464 & 33 & 21 & & \\
\hline
\end{tabular}

Tabel 2.

Karakteristik artikel Psikoedukasi keluarga, pencegahan kekambuhan ODGJ

\begin{tabular}{|c|c|c|c|c|c|}
\hline $\begin{array}{c}\text { Database/ } \\
\text { Jurnal/ Temu } \\
\text { Ilmiah } \\
\end{array}$ & $\begin{array}{l}\text { Penulis/ } \\
\text { Negara }\end{array}$ & Tahun & Metode & $\begin{array}{l}\text { Diagnosa } \\
\text { Medis }\end{array}$ & $\begin{array}{c}\text { Intisari } \\
\text { (azas kemanfaatan psikoedukasi } \\
\text { keluarga pada ODGJ) }\end{array}$ \\
\hline \multicolumn{6}{|l|}{ Google Scholar } \\
\hline $\begin{array}{l}\text { Research of } \\
\text { Education and } \\
\text { Art Link in } \\
\text { Nursing } \\
\text { Journal }\end{array}$ & Sulung, Foresa & 2018 & $\begin{array}{lr}\text { Quasi } & \text { Exeriment: } \\
\text { control } & \text { group } \\
\text { design } & \end{array}$ & Skizofrenia & $\begin{array}{l}\text { Psikoedukasi keluarga lebih } \\
\text { efektif meningkatkan kepatuhan } \\
\text { berobat pasien skizofrenia } \\
\text { daripada pendidikan kesehatan }\end{array}$ \\
\hline $\begin{array}{l}\text { Medica } \\
\text { Majapahit }\end{array}$ & Sari. Wardani & 2018 & $\begin{array}{l}\text { Eksperimen: pre } \\
\text { dan pos tes grup }\end{array}$ & Skizofrenia & $\begin{array}{l}\text { Ada pengaruh kekambuhan } \\
\text { sebelum dan sesudah diberikan } \\
\text { psikoedukasi keluarga }\end{array}$ \\
\hline $\begin{array}{l}\text { Seminar } \\
\text { Nasional } \\
\text { AVoER XI } \\
\text { Palembang }\end{array}$ & $\begin{array}{l}\text { Kusumawaty, } \\
\text { Yunike, } \\
\text { Pastari, } \\
\text { Harmiyati }\end{array}$ & 2019 & $\begin{array}{l}\text { Pemberdayaan } \\
\text { keluarga }\end{array}$ & $\begin{array}{l}\text { Gangguan } \\
\text { jiwa (umum) }\end{array}$ & $\begin{array}{l}\text { Pemberdayaan keluarga melalui } \\
\text { psikoedukasi memperlihatkan } \\
\text { adanya peningkatan pemahaman } \\
\text { dan kesiapan keluarga dalam } \\
\text { merawat ODGJ dirumah }\end{array}$ \\
\hline $\begin{array}{l}\text { Jurnal } \\
\text { Keperawatan }\end{array}$ & $\begin{array}{l}\text { Mubin, } \\
\text { Rahayu }\end{array}$ & 2019 & $\begin{array}{l}\text { Eksperime: } \\
\text { randomized } \\
\text { prepost control } \\
\text { group }\end{array}$ & Skizofrenia & $\begin{array}{l}\text { Psikoedukasi keluarga mampu } \\
\text { meningkatkan kepatuhan minum } \\
\text { obat, menurunkan kekambuhan } \\
\text { dan meningkatkan kemampuan } \\
\text { merawat ODGJ }\end{array}$ \\
\hline $\begin{array}{l}\text { Jurnal } \\
\text { Keperawatan } \\
\text { Indonesia }\end{array}$ & $\begin{array}{l}\text { Fahrizal, } \\
\text { Mustikasari, } \\
\text { Daulima }\end{array}$ & 2020 & Studi Kasus & $\begin{array}{l}\text { Gangguan } \\
\text { jiwa (umum) }\end{array}$ & \begin{tabular}{lrr} 
Psikoedukasi & \multicolumn{2}{r}{ keluarga } \\
menunjukkan & penurunan tanda \\
dan gejala risiko perilaku \\
kekerasan
\end{tabular} \\
\hline
\end{tabular}




\begin{tabular}{|c|c|c|c|c|c|}
\hline $\begin{array}{l}\text { Database/ } \\
\text { Jurnal/ Temu } \\
\text { Ilmiah }\end{array}$ & $\begin{array}{l}\text { Penulis/ } \\
\text { Negara }\end{array}$ & Tahun & Metode & $\begin{array}{l}\text { Diagnosa } \\
\text { Medis }\end{array}$ & $\begin{array}{c}\text { Intisari } \\
\text { (azas kemanfaatan psikoedukasi } \\
\text { keluarga pada ODGJ) }\end{array}$ \\
\hline \multirow[t]{7}{*}{ ProQuest } & $\begin{array}{l}\text { Ceyda } \\
\text { Basogul, } \\
\text { Kadriye } \\
\text { Buldukoglu, } \\
\text { Turki }\end{array}$ & 2015 & $\begin{array}{l}\text { Literature Review } \\
5 \text { artikel Nasional } \\
\text { dan Internasional }\end{array}$ & Depresi & 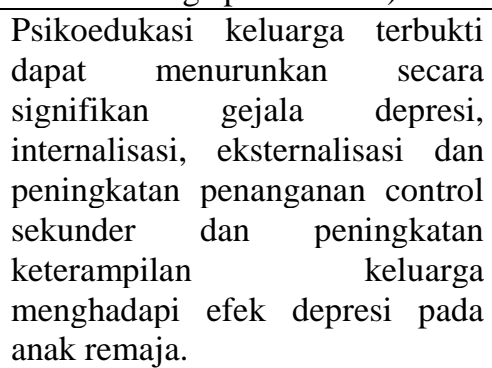 \\
\hline & Ran, et. al & 2015 & 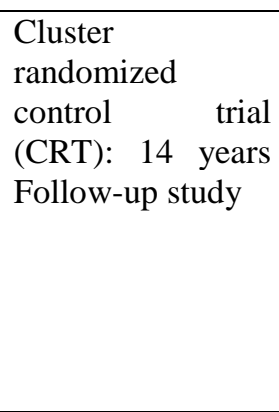 & Skizofrenia & $\begin{array}{l}\text { Intervensi keluarga psikoedukasi } \\
\text { cenderung masih efektif dalam } \\
\text { tindak lanjut selama } 14 \text { tahun } \\
\text { setalah perawatan dirumah, } \\
\text { terutama dalam kepatuhan } \\
\text { pengobatan dan fungsi sosial } \\
\text { pasien serta cenderung lebih } \\
\text { efektif pada keluarga yang } \\
\text { memiliki anggota keluarga yang } \\
\text { ikut berperan aktif }\end{array}$ \\
\hline & $\begin{array}{l}\text { Rahman, } \\
\text { Ranjbar, } \\
\text { Ebrahim, } \\
\text { Hosseinzadeh }\end{array}$ & 2015 & $\begin{array}{l}\text { Quasi } \\
\text { eksperimen, } 2 \\
\text { kelompok pre dan } \\
\text { pos tes }\end{array}$ & Skizofrenia & $\begin{array}{lr}\text { Psikoedukasi } & \text { keluarga } \\
\text { meningkatkan sikap } & \text { keluarga } \\
\text { terhadap kesiapan merawat } \\
\text { anggota keluarga skizofrenia. }\end{array}$ \\
\hline & $\begin{array}{l}\text { MacPhero, } \\
\text { Koons, Leffler, } \\
\text { Fristad }\end{array}$ & 2016 & $\begin{array}{l}\text { pilot open trial } \\
\text { evaluated } \\
\text { pretreatment, } \\
\text { posttreatment, } \\
\text { follow-up } 6 \text { bulan, } \\
\text { dan follow-up } 12 \\
\text { bulan, dan } \\
\text { dianalisis melalui } \\
\text { pemodelan linear } \\
\text { hierarkis. }\end{array}$ & $\begin{array}{l}\text { Childhood } \\
\text { mood } \\
\text { disorders }\end{array}$ & $\begin{array}{l}\text { Anak-anak dengan gangguan } \\
\text { bipolar dan keluarga dengan } \\
\text { riwayat perawatan terbatas } \\
\text { sebagian besar diuntungkan dari } \\
\text { intervensi multi family } \\
\text { psychoeducation dari pada pada } \\
\text { remaja yang memiliki gangguan } \\
\text { mood. }\end{array}$ \\
\hline & $\begin{array}{l}\text { Sankalita } \\
\text { Mukherjee }\end{array}$ & 2017 & Artikel bebas & Bipolar & $\begin{array}{l}\text { Psikoedukasi keluarga pada } \\
\text { caregiver keluarga membantu } \\
\text { mencegah kekambuhan pasien } \\
\text { bipolar }\end{array}$ \\
\hline & Connolly, et. al & 2018 & $\begin{array}{l}\text { Multi-family } \\
\text { psychoeducation } \\
\text { psichoterapy }\end{array}$ & Autis & $\begin{array}{l}\text { Intervensi psikoterapi dan } \\
\text { psikoedukasi } \\
\text { menunjukkan temuan positif dan } \\
\text { menjanjikan dalam kemampuan } \\
\text { keluarga merawat anak dengan } \\
\text { autis dirumah dan mengurangi } \\
\text { ketergantungan ke fasilitas } \\
\text { layanan kesehatan. }\end{array}$ \\
\hline & $\begin{array}{l}\text { Sampogna, et. } \\
\text { al }\end{array}$ & 2018 & $\begin{array}{l}\text { Multicenter, } \\
\text { controlled dan } \\
\text { outpatient trial, } \\
\text { sampel 123 pasien } \\
\text { dan 139 keluarga }\end{array}$ & Bipolar & $\begin{array}{l}\text { Psikoedukasi keluarga efektif } \\
\text { dalam meningkatkan strategi } \\
\text { penanganan adaptif dari kerabat } \\
\text { pasien dengan tipe bipolar namun } \\
\text { diperlukan studi lebih lanjut } \\
\text { dalam membuktikan manfaat } \\
\text { jangka panjang dari intervensi } \\
\text { ini. }\end{array}$ \\
\hline
\end{tabular}




\begin{tabular}{|c|c|c|c|c|c|}
\hline \multirow[t]{2}{*}{$\begin{array}{l}\text { Database/ } \\
\text { Jurnal/ Temu } \\
\text { Ilmiah }\end{array}$} & $\begin{array}{l}\text { Penulis/ } \\
\text { Negara }\end{array}$ & Tahun & Metode & $\begin{array}{l}\text { Diagnosa } \\
\text { Medis }\end{array}$ & $\begin{array}{c}\text { Intisari } \\
\text { (azas kemanfaatan psikoedukasi } \\
\text { keluarga pada ODGJ) }\end{array}$ \\
\hline & $\begin{array}{l}\text { Yasaman } \\
\text { Mottaghipour, } \\
\text { Maryam } \\
\text { Tabatabaee/ } \\
\text { Iran }\end{array}$ & 2019 & $\begin{array}{l}\text { Literature Review } \\
\text { sampai tahun } \\
2018 \text { menemukan } \\
48 \text { artikel: } 27 \\
\text { randomized } \\
\text { cotrolled trials } \\
\text { dan } 20 \text { quasi } \\
\text { experiment dan } 1 \\
\text { laporan } \\
\text { pengembangan } \\
\text { layanan }\end{array}$ & $\begin{array}{l}\text { Skizofrenia/ } \\
\text { Psikosis/ } \\
\text { bipolar }\end{array}$ & $\begin{array}{l}\text { Temuan utama penelitian ini } \\
\text { adalah penurunan yang signifikan } \\
\text { dalam tingkat kekambuhan dan / } \\
\text { atau tingkat rawat inap dan } \\
\text { penurunan yang signifikan dari } \\
\text { beban dan kesusahan keluarga. }\end{array}$ \\
\hline $\begin{array}{l}\text { Sage } \\
\text { Publications }\end{array}$ & $\begin{array}{l}\text { Day, Starbuck, } \\
\text { Petrakis }\end{array}$ & 2017 & $\begin{array}{l}\text { A Purpose-design } \\
\text { pre and post- } \\
\text { intervention: Re- } \\
\text { evaluation of } \\
\text { practice after10 } \\
\text { years } \\
\text { psikoeducation }\end{array}$ & Psikosis & $\begin{array}{l}\text { Psikoedukasi keluarga terbukti } \\
\text { secara signifikan meningkatka } \\
\text { dukungan keluarga dalam } \\
\text { program pemulihan, pengobatan } \\
\text { dan pencegahan kekambuhan } \\
\text { pada pasien psikosis }\end{array}$ \\
\hline \multirow[t]{4}{*}{ Science Direct } & $\begin{array}{l}\text { Petrakis, } \\
\text { Laxton }\end{array}$ & 2016 & Kualitatif & Psikosis & $\begin{array}{l}\text { Psikoedukasi keluarga pada } \\
\text { psikosis episode pertama dapat } \\
\text { membantu }\end{array}$ \\
\hline & Camacho et. al & 2017 & $\begin{array}{l}\text { Multi-centre } \\
\text { pragmatic } \\
\text { randomized } \\
\text { cotrolled trial }\end{array}$ & Bipolar & $\begin{array}{l}\text { Psiekoedukasi } \\
\text { meningkatkan pemulihan pasien } \\
\text { bipolar }\end{array}$ \\
\hline & Reins et. al & 2018 & $\begin{array}{l}\text { Perbandingan } \\
\text { Internet-based } \\
\text { cognitive } \\
\text { behavior therapy } \\
\text { (iCBT) and online } \\
\text { psychoeducation } \\
\text { (OPE) }\end{array}$ & Depresi & $\begin{array}{l}\text { CBT dan OPE efektif dalam } \\
\text { mengurangi gejala depresi, tetapi } \\
\text { dengan iCBT memiliki lebih } \\
\text { cepat berefek dalam mengurangi } \\
\text { depresi pada pasien yang tidak } \\
\text { memiliki riwayat psikoterapi } \\
\text { sebelumnya namun ada } \\
\text { kecenderungan memiliki efek } \\
\text { negative sehingga harus } \\
\text { dipertimbangkan } \\
\text { penggunaanya. }\end{array}$ \\
\hline & Chien et. al & 2019 & $\begin{array}{l}18 \text {-month } \\
\text { randomized } \\
\text { controlled trial }\end{array}$ & Skizofrenia & $\begin{array}{l}\text { Psikoedukasi dapat menjadi } \\
\text { intervensi yang efektif untuk } \\
\text { orang dewasa dengan skizofrenia } \\
\text { tahap awal dan memberikan efek } \\
\text { jangka panjang pada fungsi dan } \\
\text { kondisi kejiwaan pasien }\end{array}$ \\
\hline \multirow[t]{2}{*}{ SpringerLink } & Chen et. al & 2018 & Kualitatif & $\begin{array}{l}\text { Manik dan } \\
\text { bipolar }\end{array}$ & $\begin{array}{l}\text { Psikoedukasi jangka pendek } \\
\text { efektif pada pasien dengan manik } \\
\text { dan bipolar }\end{array}$ \\
\hline & Katsuki et. al & 2018 & $\begin{array}{l}\text { Randomized } \\
\text { control trial }\end{array}$ & $\begin{array}{l}\text { Depresi } \\
\text { mayor } \\
\text { kronis }\end{array}$ & $\begin{array}{l}\text { Psikoedukasi keluarga tidak } \\
\text { significant untuk mengurangi } \\
\text { tekanan psikologis anggota } \\
\text { keluarga yang memiliki pasien } \\
\text { dengan depresi mayor kronis }\end{array}$ \\
\hline
\end{tabular}




\section{PEMBAHASAN}

Psikoedukasi kepada anggota keluarga telah muncul sebagai prasyarat penting untuk perawatan dan rehabilitasi psikiatris modern, karena melalui psikoedukasi banyak masalah yang berhubungan dengan perawatan pasien dan kepatuhan terhadap perawatan dapat berhasil ditangani. Menjadi tambahan yang sangat diperlukan untuk perawatan psikiatri modern, lebih efektif dalam menargetkan semua area penyakit dan fungsionalitas pasien dengan cukup sesuai daripada pendekatan berbasis terapi tunggal (Mukherjee, 2017). Psikoedukasi Keluarga adalah sebuah metode yang digunakan dalam rangka memberikan informasi dan keterampilan melakukan perawatan kesehatan mental kepada anggota keluarga yang mengalami gangguan jiwa. Luaran Psikoedukasi keluarga ialah menjadikan keluarga sebagai pelaku asuh bagi ODGJ (Ngoc, Weiss, \& Trung, 2016; Sin, Gillard, Spain, Cornelius, Chene, \& Henderson, 2017; Dewi, Daulima, \& Wardan, 2020).

Adapun keefektifan psikoedukasi keluarga diungkapkan oleh Ran, et. al, 2015; Basogul \& Buldukoglu, 2015; MacPheron, Koons, Leffler \& Fristad, 2016; Petrakis \& Laxton, 2016; Munkherjee, 2017; Day, Starbuck \& Petrakis, 2017; Camacho, et. al, 2017; Sampogna, et. al, 2018; Sulung \& Foresa, 2018; Sari \& Wardani, 2018; Chen, at. al, 2018; Mubin \& Rahayu, 2019; Mottaghipour \& Tabatabaee, 2019; dan Chien, et.al, 2019; pada gangguan jiwa skizofrenia/ psikosis (Ran, et. al, 2015; Petrakis \& Laxton, 2016; Day, Starbuck \& Petrakis, 2017; Chen, at. al, 2018; Sari \& Wardani, 2018; Mubin \& Rahayu, 2019; Mottaghipour \& Tabatabaee, 2019; Chien, et.al, 2019); Bipolar (Munkherjee, 2017; Camacho, et. al, 2017; Sampogna, et. al, 2018; Mottaghipour \& Tabatabaee, 2019); depresi (Reins, et. al, 2018; Katsuki, et. al, 2018); Autis (Connolly, et. al, 2018); gangguan mood pada remaja (MacPheron, Koons, Leffler \& Fristad, 2016) dan manik (Chen, at. al, 2018)

Disamping efektif dalam sebagaian jenis gangguan jiwa, psikoedukasi keluarga juga efektif dalam mencegah kekambuhan ODGJ pada pasien skizofrenia/ psikosis (Petrakis \& Laxton, 2016;
Day, Starbuck \& Petrakis, 2017; Sari \& Wardani, 2018; Mubin \& Rahayu, 2019; Mottaghipour \& Tabatabaee, 2019); bipolar (Mukherjee, 2017; Chen, at. al, 2018; Mottaghipour \& Tabatabaee, 2019); manik (Chen, at. al, 2018); Depresi (Reins et. al, 2018). Efektivitas pencegahan kekambuhan tersebut antara lain telah dibuktikan dibeberapa negara antara lain: Brazil (Lima, et. al, 2017); Jepang (Shiraishi, et. al, 2019); Iran (Mirsepassi, et. al, 2018); Nepal (Gupta, et. al, 2018); Prancis (Villani, 2019); Indonesia khususnya di Yogyakarta (Marchira, et. al, 2019). Sedangkan penelitian Harvey, (2018) menyebutkan metode ini efektif dilaksanakan dihampir sebagian besar di dunia.

Keefektifan tersebut pada peningkatan pemahaman keluarga (Kusumawaty, Yunike, Pastari \& Harmiyati, 2019; Basogul \& Buldukoglu, 2015; Sampogna, et. al, 2018; ); menyediakan sumber daya dan dukungan (Kusumawaty, Yunike, Pastari \& Harmiyati, 2019; Basogul \& Buldukoglu, 2015; Rahmani, Ranjbar, Ebrahimi, \& Hosseinzadeh, 2015; Connolly, et. al, 2018; Petrakis \& Laxton, 2016;); menghasilkan peningkatan keteraturan kontak dengan penyedia kesehatan (Connolly, et. al, 2018;); kepatuhan dengan farmakoterapi (Mubin \& Rahayu, 2019) dan menurunkan tanda dan gejala risiko perilaku kekerasan (Fahrizal, Mustikasari \& Daulima, 2020).

Hambatan dalam pelaksanaan psikoedukasi keluarga ialah masih adanya stigma pada masyarakat secara umum yang cenderung dapat mempengaruhi hasil psikoedukasi keluarga dan keterbatasan sumber daya rumah sakit (Mirsepassi, et. al, 2018); keenganan menerapkannya (Lima, et. al, 2017). Stigma disebabkan karena ketidaktahuan tentang ODGJ (Tristiana, Fitryasari, \& Nihayati, 2018) dan proses penyembuhan serta pencegahan kekambuahan yang pada akhirnya dapat mempengaruhi ketidakmauan keluarga untuk merawat dan mendukung program pemulihan dan pencegahan kekambuhan ODGJ di rumah. Stigma dapat mencegah individu dan kelompok untuk diterima seutuhnya secara sosial (Smetana, 2020); 
dan cenderung membuat keluarga mengucilkan ODGJ karena dianggap aib keluarga (Schierenbeck, Johansson, Andersson, \& Rooyen, 2014).

Keterbatasan sumberdaya rumah sakit juga menjadi hambatan dalam pelaksanaan psikoedukasi. Keterbatasan ini lebih dikaitkan dengan fasilitas dan tenaga kesehatan yang melaksanakan psikoedukasi (Mirsepassi, et. al, 2018). Seperti halnya di Papua, sumber daya kesehatan masih menjadi polemik pelayanan kesehatan secara umum dan pelayanan kesehatan jiwa dikarenakan Papua hanya memiliki satu rumah sakit jiwa dan sumber daya tenaga kesehatan yang melakukannya. Sebagai gambaran bahwa sepanjang pengetahuan penulis di Papua belum dilakukan psikoedukasi keluarga dalam proses pencegahan kekambuhan ODGJ mengingat keterbatasan sumberdaya dan kondisi geografis. Untuk itu pada konteks ini, ada dua hal yang bisa dilakukan yakni: melakukan pelatihan psikoedukasi keluarga bagi perawat-perawat/ tenaga kesehatan yang akan melakukan psikoedukasi yang berasal dari kabupaten/ kota yang ada di Papua dan kedua pendamping yang mendapingi ODGJ saat mengembalikan kerumah masih-masing harus yang sudah dilatih psikoedukasi sehingga setelah sampai dirumah tenaga kesehatan tersebut dapat menjalankan Berdasarkan yang telah diuraikan dari hasil-hasil riset yang penulis identifikasi dan dari segi keefektivan psikoedukasi keluarga dalam pemanfaatannya untuk mencegah kekambuhan dan keterbatasan yang ada di Papua maka penulis dapat berasumsi bahwa peluang psikoedukasi keluarga dalam mencegah kekambuhan ODGJ dapat diterapkan di Papua dalam mengatasi keterbatasan sumber daya kesehatan.

\section{SIMPULAN}

Psikoedukasi keluarga efektik dan memiliki kaitan kuat dapat dipergunakan dalam promosi kepatuhan dan pencegahan ODGJ di berbagai jenis gangguan jiwa. Untuk itu psikoedukasi keluarga dapat dipergunakan sebagai alternative pencegahan kekambuhan ODGJ di Papua yang memiliki keterbatasan sumber daya baik baik fasilitas kesehatan, tenaga kesehatan maupun aspek geografis di Papua. Untuk itu Pemerintah Daerah Provinsi dan Kabupaten/Kota diharapkan dapat mendukung program psikoedukasi keluarga dalam mempercepat pemulihan dan pencegahan kekambuhan ODGJ.

\section{DAFTAR PUSTAKA}

Basogul, C., \& Buldukoglu, K. (2015). Ebeveyninde depresyon olan ergenlerde depresyonu önlemede aile odakli psikoegitim uygulamalari: Sistematik derleme/ family-based psychoeducation programs for prevention of depression in adolescents with depressed parents: A systematic review. Psikiyatride Guncel Yaklasimlar, 7(3), 265-279. Retrieved from https://search.proquest.com/docview/17065 62591 ? accountid $=17242$

BPS a (2019). Jumlah Penduduk Papua. Available from: https://papua.bps.go.id/quickMap.html

BPS b (2019). Jumlah Penduduk Papua Barat. Available from: https://papuabarat.bps.go.id/quickMap.html

Camacho, E. M., Ntais, D., Jones, S., Riste, L., Morriss, R., Lobban, F., \& Davies, L. M. (2017). Cost-effectiveness of structured group psychoeducation versus unstructured group support for bipolar disorder: Results from a multi-centre pragmatic randomised controlled trial. Journal of Affective Disorders, 211, 27-36 doi:10.1016/j.jad.2017.01.005

Charlson, F., Ommeren, M.V., Flaxman, A., Cornett, J., Whiteford, H., \& Saxena, S. (2019). New WHO prevalence estimates of mental disorders in conflict settings: a systematic review and meta-analysis Lancet, 394: 240-250 http://dx.doi.org/10.1016/ S01406736(19)30934-1

Chen, R., Xi, Y., Wang, X. et al. Perception of inpatients following remission of a manic episode in bipolar I disorder on a groupbased Psychoeducation program: a qualitative study. BMC Psychiatry 18, 26 (2018). https://remotelib.ui.ac.id:2116/10.1186/s12888-018$\underline{1614-1}$ 
Chien, W. T., Cheng, H. Y., McMaster, T. W., Yip, A. L. K., \& Wong, J. C. L. (2019). Effectiveness of a mindfulness-based psychoeducation group programme for early-stage schizophrenia: An 18-month randomised controlled trial. Schizophrenia Research, 212, 140-149. doi:10.1016/j.schres.2019.07.053

Connolly, S., Kathleen, C. G., Chung, W., Tabern, K., Guiou, T., Wynn, J., \& Fristad, M. (2018). Multi-family psychoeducational psychotherapy (MF-PEP) for children with high functioning autism spectrum disorder. Journal of Contemporary Psychotherapy, 48(3), 115-121. doi:http://dx.doi.org/10.1007/s10879-0189386-y

Day, K., Starbuck, R., \& Petrakis, M. (2017). Family group interventions in an early psychosis program: A re-evaluation of practice after 10 years of service delivery. International Journal of Social Psychiatry, 63(5), 433-438. https://doi.org/10.1177/0020764017710301

Dewi, Daulima \& Wardani. (2019). Managing family burden through combined family psychoeducation and care decision without pasung therapies. Enfermería Clínica (English Edition), 29, 76-80. Retrieved from

https://doi.org/10.1016/j.enfcli.2019.04.012

Eni, K.Y \& Herdiyanto, Y.K. (2018). Dukungan sosial keluarga terhadap pemulihan orang dengan skizofrenia (ODS) di Bali. Jurnal Psikologi Udayana, 5(3): 486-500.

Fahrizal, Yanuar, Mustikasari, Daulima, Novy Helena Cahtarina (2020). Changes in the signs, symptoms, and anger management of patients with a risk of violent behavior after receiving assertive training and family psychoeducation using roy's theoretical approach: a case report. Jurnal Keperawatan Indonesia Vol 23 No. 1; DOI: 10.7454/jki.v23i1.598

Gupta, A., Spoorthy, M., Gurung, B., Jha, R., \& Acharya, B. (2018). s206. knowledge about causes of relapse during psychoeducation in patients living with schizophrenia- a qualitative analysis. Schizophrenia
Bulletin, 44(suppl_1), S405-S406. doi:10.1093/schbul/sby018.993

Harvey, C. (2018). Family psychoeducation for people living with schizophrenia and their families. BJPsych Advances, 24(1), 9-19. doi:10.1192/bja.2017.4

Katsuki, F., Takeuchi, H., Inagaki, T. et al. Brief multifamily Psychoeducation for family members of patients with chronic major depression: a randomized controlled trial. BMC Psychiatry 18, $207 \quad$ (2018). https://remotelib.ui.ac.id:2116/10.1186/s12888-018$\underline{1788-6}$

Kementerian Kesehatan (2018). Laporan Riset Kesehatan Dasar 2018. ISBN 978-602-373118-3

Kusumawaty, Yunike, Pastari, M \& Harmiyanti, L (2019) Pemberdayaan Keluarga melalui psikoedukasi perawatan orang dengan gangguan jiwa di rumah. Seminar Nasional AVoER XI 2019.

Kyriopoulos, I.L., Zavras, D., Skroumpelos, A., Mylona, K., Athanasakis, K., Kyriopoulos, J. (2016). Barriers in Access to Healthcare services for chronic patients in times of austerity: An empirical approach in Greece. International Journal Equity Health, 13. http://doi.org/10.1186/14759276-13-54.

Lima, F., Selau, T., Menegalli, V., Magalhães, P., \& Rosa, A. (2017). Brief family psychoeducation program for caregivers of inpatients with severe mental illness. European Psychiatry, 41, S789S789. doi:10.1016/j.eurpsy.2017.01.1511

Marchira, C. R., Supriyanto, I., Subandi, S., Good, M. J. D., \& Good, B. J. (2019). Brief interactive psychoeducation for caregivers of patients with early phase psychosis in yogyakarta, indonesia. Early Intervention in Psychiatry, 13(3), 469-476. doi:10.1111/eip.12506

MacPherson, H. A., Mackinaw-Koons, B., Leffler, J. M., \& Fristad, M. A. (2016). Pilot effectiveness evaluation of community-based multi-family psychoeducational psychotherapy for 
childhood mood disorders. Couple and Family Psychology: Research and Practice, 5(1), 43-59. doi:http://dx.doi.org/10.1037/cfp0000055

Maglaya. (2009). Nursing practice in the community. 5th Ed. Marikina City: Argonauta Corporation.

Mirsepassi, Z., Tabatabaee, M., Sharifi, V., \& Mottaghipour, Y. (2018). Patient and family psychoeducation: Service development and implementation in a center in iran. International Journal of Social Psychiatry, 64(1), 73-79. doi:10.1177/0020764017747910

Mottaghipour, Y., \& Tabatabaee, M. (2019). Family and patient psychoeducation for severe mental disorder in iran: A review. Iranian Journal of Psychiatry, 14(1), 84-108. doi:http://dx.doi.org/10.18502/ijps.v14i1.42 8

Mubin, Mohmmad Fatkhul \& Rahayu, Desi Ariyana (2019). Pengaruh terapi psikoedukasi keluarga skizofrenia paranoid terhadap kepatuhan minum obat pasien. Junrla Keperawatan Vol. 11 No. 2 LPPM Sekola Tinggi Ilmu Kesehatan Kendal. EISSn 2549-8118

Mukherjee, S. (2017). Impact of psycho-education on burden and other correlates of caregivers of patients suffering from bipolar mood disorder. Indian Journal of Positive Psychology, 8(1), 87-91. Retrieved from https://search.proquest.com/docview/18912 59227? accountid=17242

Ngoc, T.N., Weiss, B., \& Trung, L.T. (2016). Effects of the Family Schizophrenia Psychoeducation Program for Individuals with Recent Onset Schizophrenia in Viet Nam. Asian Journal Psychiatr, 22: 162166. Doi: 10.1016/j.ajp.2016.06.001

Petrakis, M., \& Laxton, S. (2017). Intervening early with family members during firstepisode psychosis: An evaluation of mental health nursing psychoeducation within an inpatient unit. Archives of Psychiatric Nursing, 31(1), 48-54. doi:10.1016/j.apnu.2016.07.015
Provinsi Papua (2019). Kabupaten di Provinsi Papua. Available from: https://www.papua.go.id/view-detaillistkab-all/daftar-kabupaten.html diakses 18 Maret 2020;

Rahmani, F., Ranjbar, F., Ebrahimi, H., \& Hosseinzadeh, M. (2015). The effects of group psychoeducational programme on attitude toward mental illness in families of patients with schizophrenia, 2014. Journal of Caring Sciences, 4(3), 243-251. Retrieved from https://search.proquest.com/docview/17204 58905? accountid $=17242$

Ran, M., Chan, C. L., Ng, S., Guo, L., \& Xiang, M. (2015). The effectiveness of psychoeducational family intervention for patients with schizophrenia in a 14-year follow-up study in a chinese rural area. Psychological Medicine, 45(10), 2197-2204.

doi:http://dx.doi.org/10.1017/S0033291715 000197

Reins, J. A., Boß, L., Lehr, D., Berking, M., \& Ebert, D. D. (2019). The more I got, the less I need? efficacy of internet-based guided self-help compared to online psychoeducation for major depressive disorder. Journal of Affective Disorders, 246, 695-705. doi:10.1016/j.jad.2018.12.065

Sampogna, G., Luciano, M., Valeria, D. V., Malangone, C., Rosa, C. D., Giallonardo, V., . . . Fiorillo, A. (2018). The effects of psychoeducational family intervention on coping strategies of relatives of patients with bipolar I disorder: Results from a controlled, real-world, multicentric study. Neuropsychiatric Disease and Treatment, 14, 977-989. doi:http://dx.doi.org/10.2147/NDT.S15927 7

Sari, Dhita Kurnia \& Wardani, Lingga Kusuma (2018) Efektifitas pemberian family psychoeducation (FPE) terhadap kekambuhan penderita Skizofrenia di Kota Kediri. Medica Majapahit, Vol. 10 No. 1

Schierenbeck, I., Johansson, P., Andersson, L.M., \& Rooyen, V.D. (2014). Barriers to accessing and receiving mental health care 
in Eastern Cape, South Africa. Article in health and human rights, 5(12): 110-123.

Sin, J., Gillard, S., Spain, D., Cornelius, V., Chene, T., \& Henderson, C. (2017). Effectiveness of psychoeducational interventions for family carers of people with psychosis: A systematic review and meta-analysis. Clinical psychology review, 56: $13-24$. http://dx.doi.org/10.1016/j.cpr.2017.05.002.

Shiraishi, N., Watanabe, N., Katsuki, F., Sakaguchi, H., \& Akechi, T. (2019). Effectiveness of the japanese standard family psychoeducation on the mental health of caregivers of young adults with schizophrenia: A randomised controlled trial. BMC Psychiatry, 19(1), 263-12. doi:10.1186/s12888-019-2252-y

Smetana, Michal (2020). Nuclear Deviance: stigma politic and the rules of the nonproliferation game. Palgrave macmillan: Springrt Nature, Switzerland, ISBN: 978-3$030-24225-1$

Sulung, Neila \& Foresa Nice (2018). Efektifitas intervensi psikoedukasi terhadap kepatuhan berobat pasien skizofrenia. REAL in Nursing Journal (RNJ) Vol. 1 No. 1

Tristiana, R.D., Yusuf, A., Fitryasari, R., Wahyuni, S.D., \& Nihayati, H.E. (2018). Perceived barriers on mental health services by the family of patients with mental illness. International journal of nursing sciences, $\quad 5:$ 63-67. https://doi.org/10.1016/j.ijnss.2017.12.003

Villani, M. (2019). Effect of family psychoeducation and access to information on illness negative perceptions: A study on french families of persons experiencing schizophrenia. European Journal of Public Health, 29(Supplement_4) doi:10.1093/eurpub/ckz185.296 